\title{
Survey of gastrointestinal parasites in African cat fish (Clarias gariepinus) in some fish ponds in Kaduna metropolis, Nigeria
}

\author{
Maikai Victor Ambrose ${ }^{1 *}$ and Beatty Viv Maikai ${ }^{2}$ \\ ${ }^{1}$ College of Agriculture and Animal science, Ahmadu Bello University Mando, Kaduna, Nigeria. \\ ${ }^{2}$ Department of Public and Preventive Medicine, Faculty of Veterinary Medicine, Ahmadu Bello University Zaria, Nigeria. \\ ${ }^{*}$ Corresponding author. Email: ambrosev2003@yahoo.com
}

Copyright (@) 2018 Ambrose and Maikai. This article remains permanently open access under the terms of the Creative Commons Attribution License $\underline{4.0}$, which permits unrestricted use, distribution, and reproduction in any medium, provided the original work is properly cited.

Received 18th November, 2018; Accepted 8th December, 2018

\begin{abstract}
Fish is the cheapest source of protein amongst the mostly African poor population and specifically Nigeria. Investigations were conducted to determine the type of gastrointestinal (GIT) parasites affecting Clarias gariepinus within Kaduna metropolis. Three hundred (300) catfish from various ponds collected during the wet season from June 2016 to September 2016, were dissected and their mesenteric cavities were examined for GIT parasites. Out of the 300 Clarias gariepinus examined, 107 (35.6\%) were infected with GIT parasites. Four parasites namely, Monobothrium spp. (40.2\%), Polyonchobothrium claire (28.0\%), Procamallanus laevionchus (24.3\%) and Cryphobia iubilans (7.5\%) were recovered. Out of the 140 female fish examined, 62 (44.2\%) were infected with GIT parasites, while $45(28.1 \%)$ out of the 160 males examined were infected. The difference was statistically significant at $\mathrm{p}<0.05$ between the females and males. Fishes having length $>18 \mathrm{~cm}$ had higher rate of GIT parasites as seen with those $>25 \mathrm{~cm}$ having the highest prevalence $(49.1 \%)$ compared to those within 13 to $17 \mathrm{~cm}(30.8 \%)$, and the least were those 8 to $12 \mathrm{~cm}(5.3 \%)$ in length. The result of the study indicated that the association $(\mathrm{P}<0.05)$ between the prevalence of infection, sex, length and weight of the host was statistically significant $\left(X^{2}=3.96,16.34\right.$ respectively). Monobothrium spp. $(41.3 \%)$ was the most recovered GIT parasite, followed by Polyonchobothrium claire $(27.0 \%)$ and Procamallanus laevionchus $(22.2 \%)$. The rate of infection of the intestine with GIT parasites was higher (91.3\%) compared to stomach (8.7\%). No parasite was recovered in the rectum. This study has shown that catfish within Kaduna metropolis harbour GIT parasites that are both of veterinary and public health importance.
\end{abstract}

Keywords: Catfish, gastrointestinal parasites, prevalence, Kaduna.

\section{INTRODUCTION}

Fish is a cheap source of protein among the increasing population of Africa including Nigeria. This has led to increase demand for protein which has encouraged farmers to turn to aquaculture to meet this demand. Aquaculture is recognized as an alternative means of achieving food security and poverty reduction. The African cat fish (Clarias gariepinus) belongs to the family Claridae and has been known to be the most popular fish food in Nigeria (Teugels,1986). Clarias gariepinus Burchell 1822, called the African catfish is one of the most important tropical catfish species used in aquaculture in the West African region (Skelton and Teugels, 1992). The fish inhabits tropical swamps, lakes and rivers. Clarias gariepinus has been considered to hold great promise for fish farming in Africa; the fish having a wide geographical spread, a high growth rate, resistant to handling and stress, and well appreciated in a wide number of African countries. Disease is universally recognized as one of the most serious threats to the commercial success of aquaculture (Noga, 2010). Parasites usually exist in equilibrium with their host as a survival strategy. However, in instances where hosts are overcrowded such as in aquaria or in fish farms, parasitic diseases can spread very rapidly causing high mortality. Farmers are constrained 
with massive fry and fingerling mortalities, especially in culture system due to the invasion of parasitic diseases (lyaji et al., 2009). Akinsanya and Otubanjo (2006), reported that fish from African freshwater were infected by a variety of adult helminth parasites ranging from monogenaen, digenean, cestodes, nematodes, acathocephalans and aspidogastrean. Paperna (1996) reported that different helminth parasite had varying degrees of been pathogenic to fishes. Fish diseases especially parasitic diseases, reduces fish production and increase morbidity and mortality. Fish borne nematodes infections in humans are common in countries where people have a traditional custom of consuming live, raw, smoked, lightly cooked or marinated fish.

Human fish-borne nematodiosis may constitute a problem of public health in Nigeria, fish-borne nematodes, the most common species causing human infections are Anisakis spp., Pseudoterranova spp. and Gnathostoma spp., which are distributed worldwide (Arizono et al., 2011). In Kaduna, there is a paucity of information regarding the types infesting Clarias gariepinus. Thus, this investigation is therefore undertaken to carry out a survey on the gastrointestinal parasites of Clarias gariepinus.

\section{MATERIALS AND METHODS}

\section{Study area}

Kaduna, is the capital of Kaduna State is located on latitude $10^{\circ} 31^{\prime} 23^{\prime \prime} \mathrm{N}$ and longitude $7^{0} 26^{\prime} 25^{\prime \prime} \mathrm{E}$ ) in North western Nigeria. It has a land mass of $2,158 \mathrm{~km}^{2}$ and a population of 1, 331,161 (NPC, 2006 census). The vegetation cover is Sudan Savannah type, characterized by scattered short trees, shrubs and grasses. Soil type is mostly loamy to sandy type. Substantial amount of clay is also found. Kaduna is divided into Kaduna North comprising Mando, Kawo,Tudun wada, Abakpa and Central main market area. Kaduna south, comprising areas across the Kaduna river comprising Barnawa, Nasarawa, Kudenda, sabo and Goningora (Figure 1). Kaduna has a rainy season from May to October and harmattan season from November to February, while the hot season is from March to June.

\section{Collection of fish}

A total of three hundred (300) catfish specimens were randomly purchased live from fishermen producing in earthen ponds and artificial ponds from across the Kaduna metropolis and then transported to the laboratory (which laboratory?) in cool boxes for parasitological examinations. The collection was made between June 2016 and September 2016. The fishes were sorted according to different sizes. The total length of each fish was measured in centimeters $(\mathrm{cm})$ using measuring tape, while the weight of each fish was weighed in grams ( $g$ ) using a weighing balance. The fishes were identified based on external features as described by Idodo-Umeh (2003).

The sex of the fish was determined by examination of the papillae. Then, the collected fish samples were dissected and the mesenteric cavity examined for parasites.

\section{Parasitological examination}

The fishes were immobilized by cervical dislocation for easy handling prior to dissection on a dissecting board. The fishes were dissected through the abdomen by making a longitudinal slit on the ventral surface from the anus to a point level with the pectoral fins using a surgical blade. The alimentary tract was isolated stretched out and grouped into oesophagus, stomach and intestine. Sections were placed into three separate Petri dishes containing $0.7 \%$ saline solution. Each section was slit longitudinally and examined for parasites under a dissecting microscope. Parasites found were counted, fixed and preserved in 10\% formalin (Frimeth, 1994).

\section{Identification of parasites}

Nematodes were cleared with lactophenol while the cestode and trematodes were stained overnight with a weak Ehrlich's haematoxylin solution and passed through graduated alcohol $(30,50,70,90 \%$ and absolute) for 45 min to dehydrate, cleared in methylsalicylate. The parasites were mounted on a slide in Canada balsam. Parasites were identified using technique described by Chilton et al. (1995), Paperna $(1980,1996)$ and Williams and Jones (1994).

\section{Data analysis}

Data were analyzed using SPSS version 17. Descriptive statistics was used and Chi-square was employed to test for association between prevalence of GIT parasites and sex, age, length and weight of the fish.

\section{RESULTS}

Out of the 300 Clarias gariepinus examined, 107 (35.6\%) were infected with GIT parasites. Four type of parasites namely Cryptobia iubilans (protozoa), Monobothrium spp. (cestoda), Polyonchobothrium claire (cestoda) and Procamallanus laevionchus (nematoda), belonging to different taxonomic groups, were recovered from 107 infected Clarias gariepinus. Monobothrium spp. were the most prevalent $(40.2 \%)$, followed by Polyonchobothrium 


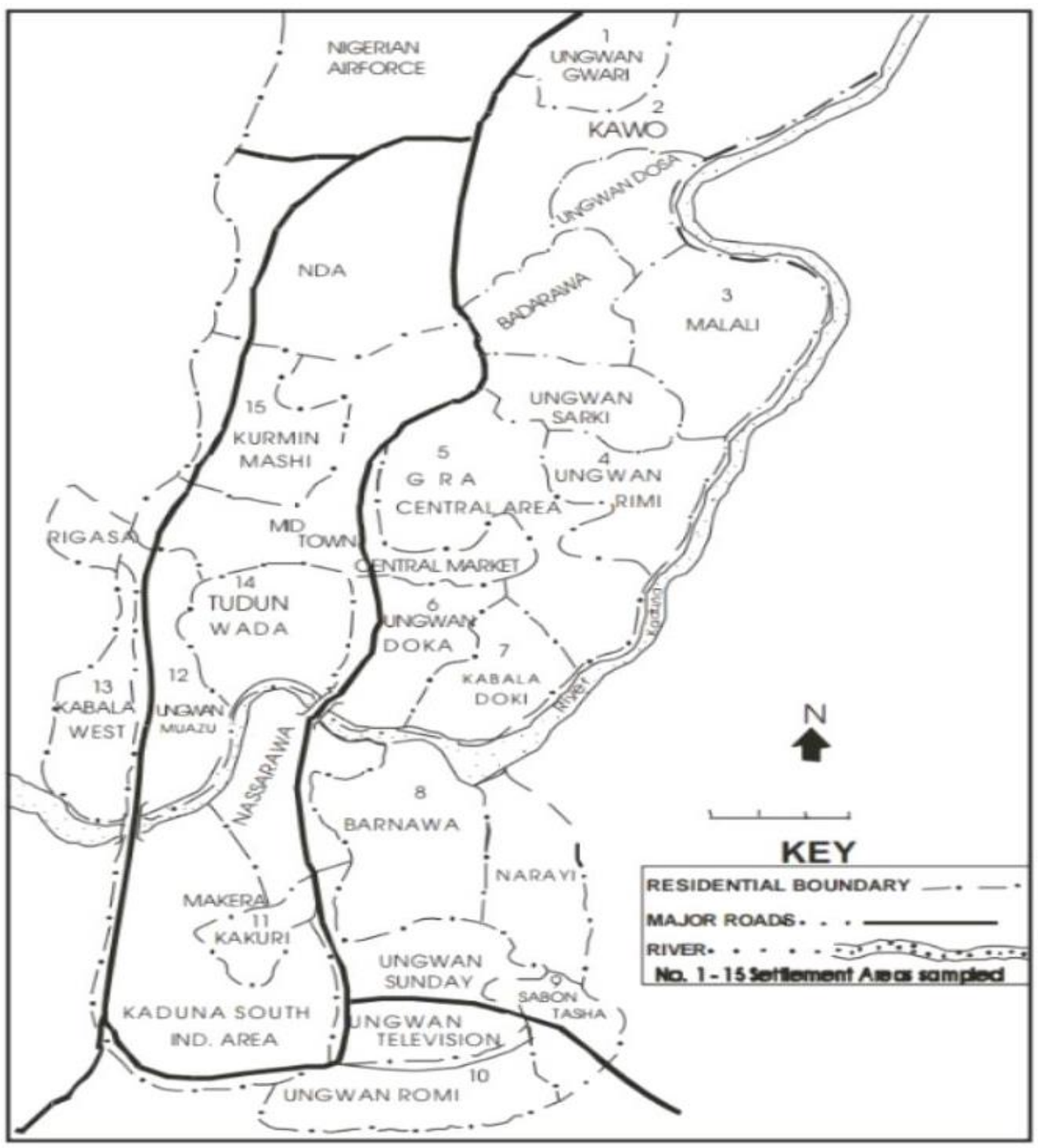

Figure 1. Kaduna Metropolis map (Yayock et al., 2014).

claire (28.0\%), Procamallanus laevionchus (24.3\%) and the least was Cryphobia iubilans (7.5\%) (Table 1).

The intensity of infection with GIT parasites in the 107 infected fish is shown in Table 2 . The intensity was highest with Monobothrium spp. (48.6\%) infection, followed by Polyonchobothrium claire (31.8\%), Procamallanus laevionchus (26.2\%) and the least was Cryphobia iubilans (11.2\%). Parasites were found in both stomach and intestine with the exception of Procamallanus laevionchus which was found only in the intestine. The rate of infection of the intestine with GIT parasites was higher (91.3\%) compared to stomach $(8.0 \%)$, this was significantly $(p>0.05)$ higher. No parasite was recovered from the rectum level.

Out of the 140 females examined, $62(44.2 \%)$ were infected with GIT parasites, while 45 (28.1\%) out of the 160 males examined were infected (Table 3 ), a sstatistically significant difference at $p<0.05$ between the females and males was noted with $X^{2}=3.96$. Fish with standard length $>18 \mathrm{~cm}$ had relatively higher rate of GIT parasites as seen with those $>25 \mathrm{~cm}$ having the highest prevalence rate (49.1\%) compared to those within 13 to $17 \mathrm{~cm}(30.8 \%), 18$ to $24 \mathrm{~cm}(18.9 \%)$ and the least were the categories in the 8 to $12 \mathrm{~cm}(5.3 \%)$ (Table 4). Likewise, the prevalence of GIT parasites among the various catfish ages and weight is in relation to the length as there was a linear relationship between length and weight/age. The fish with standard length range $>18 \mathrm{~cm}$ were heavier and they happened to be the adult ones (Table 4). Statistically significant difference at $p<0.05$ was noted in the prevalence of 
Table 1. Prevalence of species of gastrointestinal parasites in 107 infected Clarias gariepinus in Kaduna metropolis, Nigeria.

\begin{tabular}{llcc}
\hline Parasite spp & Taxonomic group & No. of fish infected & Prevalence (\%) \\
\hline Crytobia iubilans & Protozoa & 8 & 7.5 \\
Monobothrium spp & Cestoda & 43 & 40.2 \\
Polyonchobothrium clarie & Cestoda & 30 & 28.0 \\
Procamallanus laevionchus & Nematoda & 26 & 24.3 \\
Total & & 107 & \\
\hline
\end{tabular}

Table 2. Intensity of infection of gastrointestinal parasites in 107 infected Clarias gariepinus in Kaduna metropolis, Nigeria.

\begin{tabular}{|c|c|c|c|c|c|}
\hline \multirow{2}{*}{ Parasite spp } & \multirow{2}{*}{$\begin{array}{l}\text { Number of parasites } \\
\text { recovered (\%) }\end{array}$} & \multicolumn{3}{|c|}{ Location } & \multirow{2}{*}{$\begin{array}{l}\text { Intensity of } \\
\text { infection (\%) }\end{array}$} \\
\hline & & Stomach & Intestine & Rectum & \\
\hline Crytobia iubilans & $12.0(9.5)$ & 8 & 4 & 0 & 11.2 \\
\hline Monobothrium spp & $52.0(41.3)$ & 1 & 51 & 0 & 48.6 \\
\hline Polyonchobothrium clarie & $34.0(27.0)$ & 2 & 32 & 0 & 31.8 \\
\hline Procamallanus laevionchus & $28.0(22.2)$ & 0 & 28 & 0 & 26.2 \\
\hline Total/mean & $126 / 1.18$ & $11(8.7 \%)$ & $115(91.3 \%)$ & 0 & \\
\hline
\end{tabular}

Table 3. Sex-based prevalence of gastrointestinal parasites in Clarias gariepinus in Kaduna metropolis, Nigeria.

\begin{tabular}{lccc}
\hline Sex & No. of fish examined & No. of fish infected & Prevalence (\%) \\
\hline Male & $160(53.3)$ & 45 & 28.1 \\
Female & $140(46.6)$ & 62 & 44.2 \\
Total & $300(100.0)$ & 107 & 35.6 \\
\hline
\end{tabular}

Table 4. Weight and length-based prevalence of gastrointestinal parasites in Clarias gariepinus in Kaduna metropolis, Nigeria.

\begin{tabular}{lcccc}
\hline Weight & Length & No. of fish examined & No. of Fish Infected & Prevalence (\%) \\
\hline $70-100 \mathrm{~g}$ Fingerlings & $8-12 \mathrm{~cm}$ & $19(6.3)$ & 1 & 5.3 \\
$110-200$ g Juvenile & $13-17 \mathrm{~cm}$ & $26(8.6)$ & 8 & 30.8 \\
$210-300 \mathrm{~g}$ Young & $18-24 \mathrm{~cm}$ & $90(30.0)$ & 17 & 18.9 \\
$\geq 300 \mathrm{~g}$ Adults & $>25 \mathrm{~cm}$ & $165(55.0)$ & 81 & 49.1 \\
Total & & $300(100.0)$ & 107 & 35.6 \\
\hline
\end{tabular}

internal parasites among the length and weight/age of the fish with $X^{2}=16.34$. The reverse was the case with the younger ones.

\section{DISCUSSION}

The survey on the GIT parasites of Clarias gariepinus in Kaduna Metropolis, Nigeria showed an overall prevalence rate of $35.6 \%$. This relatively low prevalence could be as a result of fish collection from concrete and artificial ponds which is the new trend of producing fish and these ponds are not usually highly contaminated by sewage and other sources of contamination. Edema et al. (2008) reported that some of the factors that enhance parasitic infection in fishes include reduced oxygen content of water, increase inorganic matter in the water, and poor environmental conditions. The results are similar to Oniye et al. (2004) in Zaria, who isolated five species of helminth parasites comprising three cestodes, one nematode, and one acanthocephala. However, the overall prevalence of internal parasites in the present study was lower compared to the findings of Olofintoye (2006) who reported a value of $60.23 \%$. Akinsanya et al. (2008) reported a prevalence rate of $38.7 \%$ and Amaro et al. (2014) reported $47.0 \%$.

In the present study, the higher recovery of cestodes 
than nematodes and protozoa in the fish examined in Kaduna metropolis is similar to the findings of Oniye et al. (2004) who reported a high prevalence of cestodes and nematodes in Clarias gariepinus in Zaria. Aliyu and Solomon (2012) also reported the recovery of the nematode Procamallanus laevionchus and the cestode Polyonchobothrium clariae in C. gariepinus from lower Usman Dam, Abuja. Yakubu et al. (2002) found C. gariepinus infected by Procamallanus laevionchus in River Uke, Plateau State. The parasite fauna of $C$. gariepinus obtained in this study is similar since Kaduna could have same weather patterns as that of Zaria and Abuja. Difference in prevalence of parasites in fish could be as a result of many factors, such as water source, $\mathrm{pH}$ and temperature among others. Williams and Jones (1994) suggested that parasitism differs in various aquatic ecosystems and this is determined by the interaction between biotic and abiotic factors. Fish species that are reared in good environmental (water environment) conditions have been reported not to be easily infected with diseases (Oswald and Hulse, 1982). However, the results in this study contradicts that of Kawe et al. (2016) who reported a higher prevalence of nematodes $(50.6 \%)$ than cestode $(10.8 \%)$ and trematodes $(6.0 \%)$ the commonest infection of catfish (C. gariepinus) on sale in Abuja. The highest prevalence of parasites was found mainly in the intestine which implies that it is a more preferred predilection site; this could be due to the favourable conditions that enhance parasite survival (Owolabi, 2008). The difference between sexes was statistically significant $p<0.05$, the prevalence was higher in females $(44.2 \%)$ than males $(28.1 \%)$. The differences in prevalence between males and females in this study agrees with the findings of Imam and Dewu (2010), Bichi and Ibrahim (2009) and Mhaisen et al. (1988), who stated that female fishes were generally more liable than males to infestations with cestodes, nematodes and trematodes. This could be due to the difference of their physiological condition of the females, which could have had reduced resistance to infection by the parasites. This finding contradicts the results obtained by Akinsanya et al. (2008) and Allumma and Idowu (2011) who reported that male specimens presented a higher rate of internal parasite infestation than female.

This study also showed that the prevalence increased with the length and weight of the fishes. Low infection was found in fish length 8 to $12 \mathrm{~cm}(5.2 \%)$ and 21 to $25 \mathrm{~cm}$ $(3.92 \%)$. This may be attributed to probable differences in feeding habits with fish age and immunity. These findings are similar to the reports of Allumma and Idowu (2011) and Bichi and Ibrahim (2009) who stated that larger fishes were heavily parasitized than the smaller ones. The intensity and prevalence of parasites infection increased with increasing length, size and age of the host fish. A plausible reason why the adult fishes were infected most could be because of the longer duration of time the older fish were exposed to the agents in the water environment. Fish borne nematodes and cestode infections in humans are common in countries where people have a traditional custom of consuming live, raw, smoked, lightly cooked or marinated fish. The three major cestode zoonoses are cystic echinococcosis, alveolar echinococcosis, and cysticercosis, while common species causing human infections are Anisakis spp., Pseudoterranova spp. and Gnathostoma spp., which are distributed worldwide (Arizono et al., 2011).

\section{Conclusion}

In conclusion, the results of the present study showed that helminth parasites were prevalent in the $C$. gariepinus sampled in Kaduna Metropolis, Nigeria, however it was low compared to other studies. The study recovered four parasitic specie. Parasites are known to affect health, palatability, productivity, marketability and aesthetic value of fish and could have a potential zoonotic effect on humans. Thus, the findings of this study are expected to contribute to knowledge in the types of parasite fauna found in Clarias gariepinus in and around Kaduna metropolis.

\section{CONFLICT OF INTEREST}

The authors declare that they have no conflict of interest.

\section{REVERENCES}

Akinsanya, B., \& Otubanjo, O.A. (2006). Helminth parasites of Clarias gariepinus (Clariidae) in lekki lagoon, Lagos, Nigeria. Rev. de Biol. Trop. 54(1), 93-99.

Akinsanya, B., Hassan, A. A., \& Adeogun, A. O. (2008): Gastrointestinal helminth parasites of the fish Syndontis clarias (Siluriformes:Mchokidae) form Lekki lagoon, Lagos, Nigeria. Int J. Trop. Biol., 56, 2021-2026.

Aliyu, M. D and Solomon J.R. (2012): The intestinal parasite of Clarias gariepinus found at lower usman dam Abuja. Department of Biological Science, Faculty of Science, University of Abuja, Nigeria.

Allumma, M. I., \& Idowu, R. T. (2011). Prevalence of gills helminth of Clarias gariepinus in Baga side of lake Chad $\mathrm{J}$. Appl. Sci. Environ. Mangt. 15, 47-50.

Amaro A, Alemayehu, A. and Aylate, A. (2014). Prevalence of internal parasitic helminthes infected Oreochromis niloticus (nile tilapia), Clarias gariepinus (African catfish) and Cyprinus carpio (common carp) in Lake Hugo (Hayke), Northeast Ethiopia. School of Veterinary Medicine, Wono University, P. O. Box 1146, Dessie, Ethiopia.

Arizono, A., Miura,T., Yamada, M., Tegoshi, T., Onishi, K. (2011). Human infection with pseudoterranova azari round worm. Emerging Infectious Diseases, 17(3), 555-556.

Bichi, A., \& Ibrahim, A. (2009). A survey of ecto and intestinal parasites of Tilapia Zillii (Gervias) in Tiga lake, Kano, northern Nigeria. Bayero Journal of Pure and Applied Sciences, 2(1), 79-82.

Chilton, N. B., Gasser, R. B., \& Beveridge, I. (1995). Differences in a ribosomal DNA sequence of mor-phologically indistin- 
guishable species within the Hypodontus macropi complex (Nematoda: Strongyloidea). International Journal of Parasitology, 25(5), 647-651.

Edema, C. U., Okaka, C. E., Oboh, I. P., \& Okogub, B. O. (2008). A preliminary study of parasitic infections of some fishes from Okhuo River, Benin City, Nigeria. International Journal of Biomedical Health Sciences, 4(3), 107-112.

Frimeth, J. (1994). General procedures for parasitology. In: Suggested procedures for the detection and identification of certain finfish and shellfish pathogens, (Thoesen, J. editor). Fourth edition, Fish Health Section, Bethesda, MD: Am. Fisheries Soc. Pp. 5-6.

Froese, R. P. D. (2014): (eds). Clarias gariepinus in fish base,March 2014 version (Wikipedia search).

Idodo-Umeh, G. (2003): Freshwater Fishes of Nigeria (Taxonomy, Ecological Notes Diet and utilization). IdodoUmeh Publishers, Benin, Nigeria. p. 232.

Imam, T. S., \& Dewu, R. A. (2010). Survey of piscine ecto-and intestinal parasites of clarias species sold at Galadima road fish market Kano metropolis, Nigeria. Bioscience Research Communications, 22(4), 209-214.

Iyaji, F. O., Etim, L., \& Eyo, J. E. (2009). Parasite assemblages in fish hosts. Bio-Research, 7, 2, 561-570.

Kawe, S. M., God'spower, R. O., Balarabe, M. R., \& Akaniru, R. I. (2016). Prevalence of gastrointestinal helminth parasites of Clarias gariepinus in Abuja, Nigeria. Sokoto Journal of Veterinary Sciences, 14(2), 26-33.

Mhaisen, F. T., Al-Salim, N. K., \& Khamees, N. R. (1988). Occurrence of parasites of the freshwater mugilid fish Liza abu (Heckel) from Basrah, southern Iraq. Journal of fish Biology, 32(4), 525-532.

National Population Commission (NPC) (2006). Nation and State Population Census: 2006 Census Priority Tables (Vol 1)

Noga, E. J. (2010). Fish Disease: Diagnosis and Treatment. 2nd edn Wiley-Blackwell Publication, USA.

Olofintoye, L. K. (2006). Parasitofauna in some freshwater fish species in Ekiti State, Nigeria. Pakistan Journal of Nutrition, 5(4), 359-362.

Oniye, S. J., Adebote, D. A., \& Ayanda, O. I. (2004). Helminth parasites of Clarias gariepinus in Zaria, Nigeria. Nigerian Journal of Aquatic Sciences, 19(2), 71-76.
Oswald, E., \& Hulse, J. E. (1982). Fish aquaculture and fish disease in South East Africa, Report of a workshop held in Jakarta, Indonesia. Pp. 79.

Owolabi, O. D. (2008). Endoparasitic helminths of the upsidedown catfish, Synodontis membranaceus (Geoffroy Saint Hilarie) in Jebba Lake, Nigeria. International Journal of Zoological Research, 4(3), 181-188.

Paperna, I. (1980). Parasites, infections and diseases of fish in Africa, CIFA Tech. Paper, 7, FAO, Rome, Italy. Pp. 200.

Paperna, I. (1996). Parasites, Infections and Diseases of fishes in Africa- an update, CIFA Technical Paper No. 31, Rome, $\mathrm{FAO}, 220$

Skelton, P. H., \& Teugels, G. G. (1992). Neotype Designation for the African Catfish Clarias gariepinus (Burchell 1822) (Pisces: Siluroidei: Clariidae). Lchthyological Bull.JLB Smith Inst. Ichthyol. 56, 1-8.

Teugels, G. G. (1986). A systematic revision of the African species of the genus Clarias (Pisces: Clariidae). Annales Musee Royal de L'Afrique Centrale. Science Zoologiques, 247, 1-199.

Williams, H., \& Jones, A. (1994): Parasitic worms of fish. Taylor and Francis, Bristol, UK. p. 593.

Yakubu, D. P., Omoregie, E., Wade, J. W., \& Faringoro, D. U. (2002). A comparative study of gut helminths of Tilapia Zilli and Clarias gariepinus from river uke, plateau state, Nigeria. J. Aquatic Sci., 17(2), 137-139.

Yayock, H.C, Ndams, I.S, kogi, E., Ahmed, A.B. and Vagime, C.G (2014): Distribution of Mosquito Species in Kaduna Metropolis, Kaduna State Northern Nigeria. Nigeria Journal of Entomology, 31, 1-15. 